\title{
A SHOWY NEW PLATYSTELE (PLEUROTHALLIDINAE: ORCHIDACEAE) FROM NORTHWEST ECUADOR
}

\author{
LOU JosT ${ }^{1,2,4} \&$ GABRIEL ITURRALDE ${ }^{3}$ \\ ${ }^{1}$ Fundacion EcoMinga, 27012 de noviembre and Luis A Martinez, Banos, Tungurahua, Ecuador \\ ${ }^{2}$ Jardín Botánico de Quito, Parque Carolina, Quito, Pichincha, Ecuador \\ ${ }^{3}$ Universidad de Las Américas, Calle José Queri, Quito 170137, Pichincha, Ecuador \\ ${ }^{4}$ Author for correspondence: loujost@gmail.com
}

\begin{abstract}
A new species of Platystele (Pleurothallidinae: Orchidaceae) is described from foothill forest in the province of Carchi in northwestern Ecuador. The species has relatively large flowers for the genus, with long slender sepaline tails. It resembles Platystele caudatisepala, but is distinguished from that species by the partially connate lateral sepals, the convex lip with reflexed tip and margins, the deflexed petals, sometimes with their tips touching behind the flower, the sepals with recurved margins, and the leaves long-petiolate.

Resumen. Se describe una nueva especie de Platystele (Pleurothallidinae: Orchidaceae) de los bosques piemontanos de la provincia de Carchi en el noroccidente de Ecuador. Esta especie presenta flores relativamente grandes en relación a la mayoría de las especies del género, cuyas caudas de los sépalos son largas y delgadas. Es similar a Platystele caudatisepala pero se distingue de esa especie por sus sépalos laterales parcialmente connados, el labio convexo con la punta y márgenes reflexos, los pétalos deflexos, a veces tocando sus puntas hacia atrás de la flor, los sépalos con márgenes recurvados y las hojas largamente pecioladas.
\end{abstract}

KEY wORDS: Carchi, Ecuador, Orchidaceae, Platystele, Pleurothallidinae

Introduction. The genus Platystele Schltr. (Pleurothallidinae: Orchidaceae) is a large Neotropical genus of mostly tiny orchids, with leaves not exceeding $15 \mathrm{~cm}$, and some with flowers less than $3 \mathrm{~mm}$ across (Luer 1990). They are usually found in very wet forests, where they are inconspicuous and seldom noticed by non-specialist collectors. At the time of its most recent monograph (Luer 1990), the genus Platystele contained 73 species. Since then, four species have been removed to be placed in the recently-established genus Teagueia (Luer) Luer (1991) and at least 41 new species have been added (Karremans 2016). Genetic analysis shows that Platystele is most closely related to Scaphosepalum Pfitz. (Pridgeon et al. 2001).

Though most Platystele species have flowers only a few millimeters across, a few have relatively larger flowers (though still on small plants), and a very few may even be considered "showy". The species described here is one of the larger and showier members of the genus, with flowers exceeding $30 \mathrm{~mm}$ because of their long sepaline tails.

\section{TAXONOMIC TREATMENT}

Platystele baqueroi Jost \& Iturralde, sp. nov. (Figs. 1-4).

TYPE: Ecuador. Carchi: epiphyte on cliff-side vegetation, $1.003^{\circ} \mathrm{N}, 78.214^{\circ} \mathrm{W}$, elevation $1080 \mathrm{~m}$, May 10, 2016, L. Baquero 3100 (Holotype, QCNE!). Figs. 1-2.

Diagnosis. Similar to the widely distributed $P$. caudatisepala (C. Schweinf.) Garay, but differs in its more long-petiolate leaves, lateral sepals connate for $2 \mathrm{~mm}$ and not divergent, petals usually strongly deflexed, with tips that often meet or cross behind the flower, and adaxial surface of lip strongly convex rather than planar.

Herb, epiphytic, densely caespitose; roots slender, 0.3-0.4 mm thick. Ramicauls slender, 2-3 $\mathrm{mm}$ long, enclosed by $2-3$ thin, ribbed, imbricating, apiculate, persistent sheaths. Leaf erect, coriaceous, obovate, $12-14 \mathrm{~mm}$ in length including petiole, $4 \mathrm{~mm}$ wide, gradually narrowing into a slender 


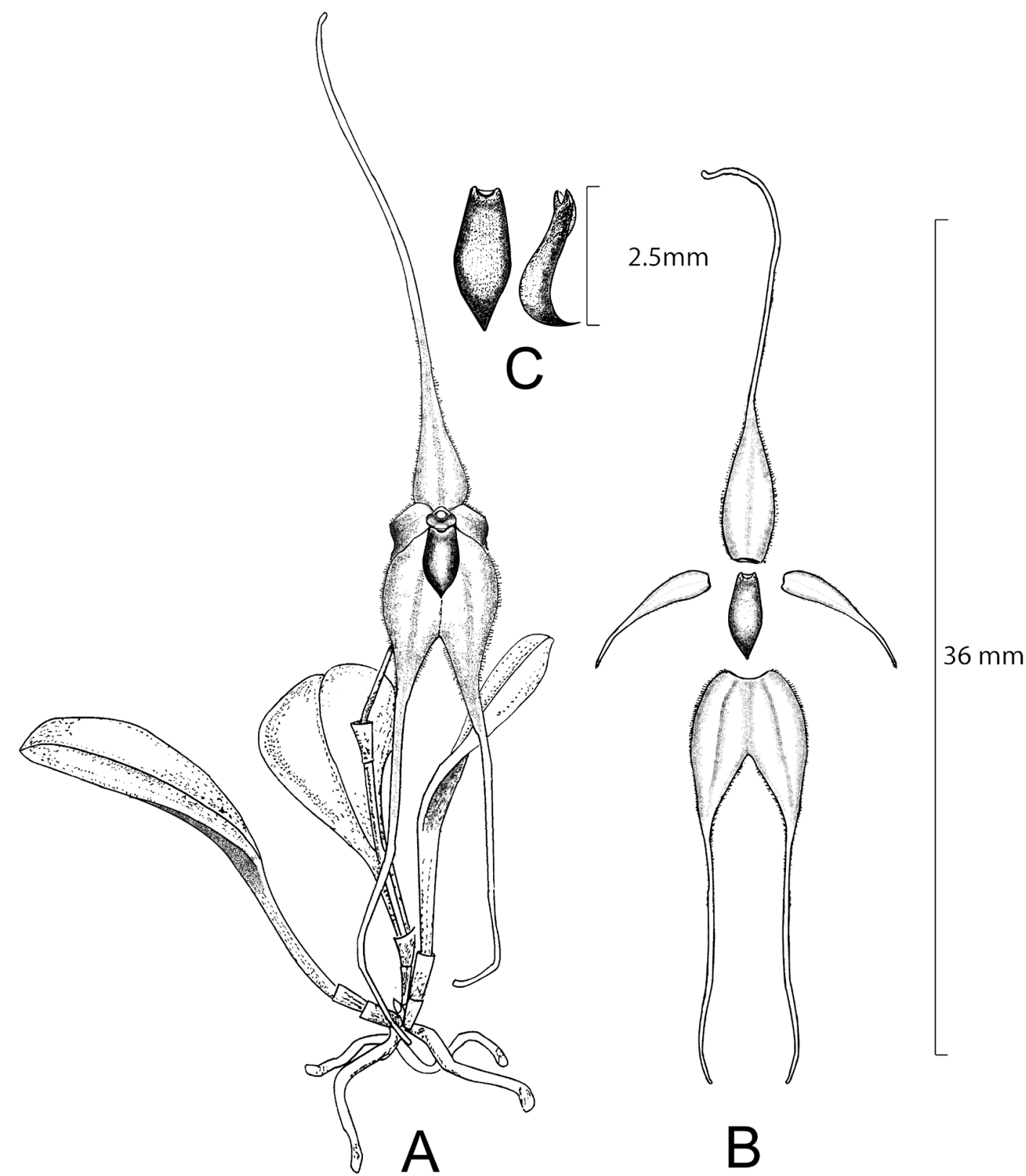

FIGURE 1. Platystele baqueroi. A, plant. B, dissection. C, lip, frontal and lateral views. Drawing by Luis Baquero from the holotype.

petiole about $4 \mathrm{~mm}$ long. Inflorescence a congested, successively many-flowered raceme up to $10 \mathrm{~mm}$ long, with an imbricating apiculate sheath, born on an erect, filiform peduncle $5 \mathrm{~mm}$ long arising laterally from the ramicaul; floral bracts thin, imbricating, apiculate, $1 \mathrm{~mm}$ long; $0.2-0.5 \mathrm{~mm}$ between flowers; pedicels straight, $1-3 \mathrm{~mm}$ long; ovary $0.5 \mathrm{~mm}$ long; sepals translucent, single-veined, with clavate cilia on margins and inner surfaces, very narrowly ovate, acute, long-attenuated; dorsal sepal yellowish, 15.0 $\mathrm{mm} \times 1.4 \mathrm{~mm}$ wide; lateral sepals yellowish with purple wash, each $15 \mathrm{~mm} \times 2 \mathrm{~mm}$, connate for 2 $\mathrm{mm}$; petals translucent yellowish washed with purple, with clavate cilia on margins, narrowly 

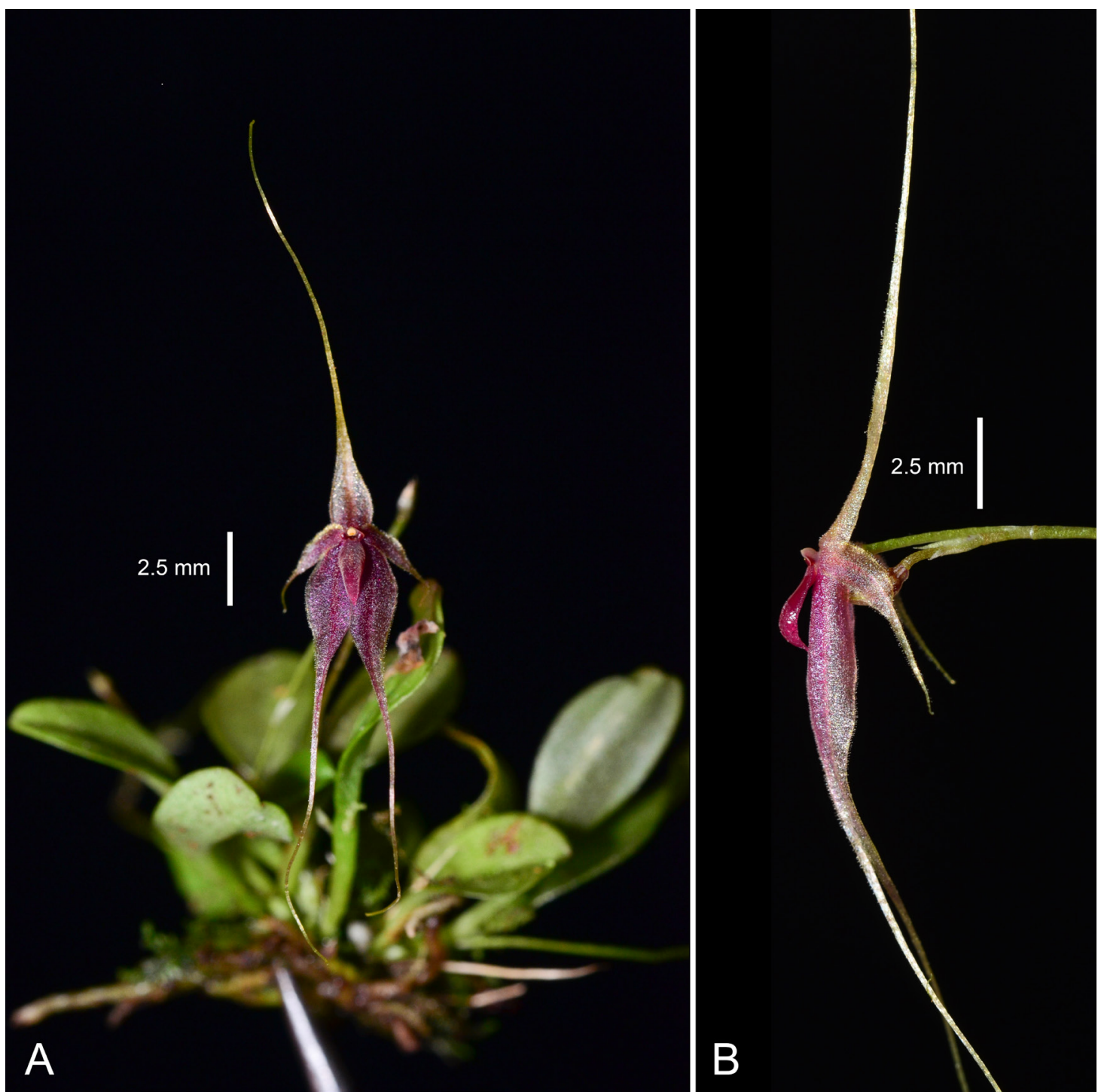

FIgURE 2. Platystele baqueroi. A, frontal view. B, lateral view. Scale bars $=2.5 \mathrm{~mm}$. Photographs of the specimen that served as the holotype by Luis Baquero.

ovate, oblique, acute, $4.0 \mathrm{~mm} \times 0.7 \mathrm{~mm}$; lip purple, three-veined, cellular-glandular, ovate, acute, convex, edges reflexed, $2.2 \mathrm{~mm}$ long, including 0.5 $\mathrm{mm}$ acuminate tip, $0.8 \mathrm{~mm}$ wide, the base truncate with small glenion; attached to column foot; column cucullate, $0.5 \mathrm{~mm} \times 0.7 \mathrm{~mm}$, the stigma bilobed.

PARAType: Ecuador. Carchi: epiphyte on cliff-side vegetation, $1.003^{\circ} \mathrm{N}, 78.214^{\circ} \mathrm{W}$, elevation $1080 \mathrm{~m}$. May 26, 2016, L. Baquero 3103, (QCNE!)

Eponymy: Named after Luis Baquero, Quito, Ecuador, enthusiastic orchidologist and conservationist who discovered this species.

This species is similar to $P$. caudatisepala, which occurs from Mexico to Ecuador at similar elevations; the discoverer Luis Baquero reports that $P$ caudatisepala are present in the same area as $P$. baqueroi. As in $P$. caudatisepala, the dorsal sepal varies greatly in length from flower to flower, and the margins of the floral parts have conspicuous clavate cilia (Fig. 3). The most obvious difference between 


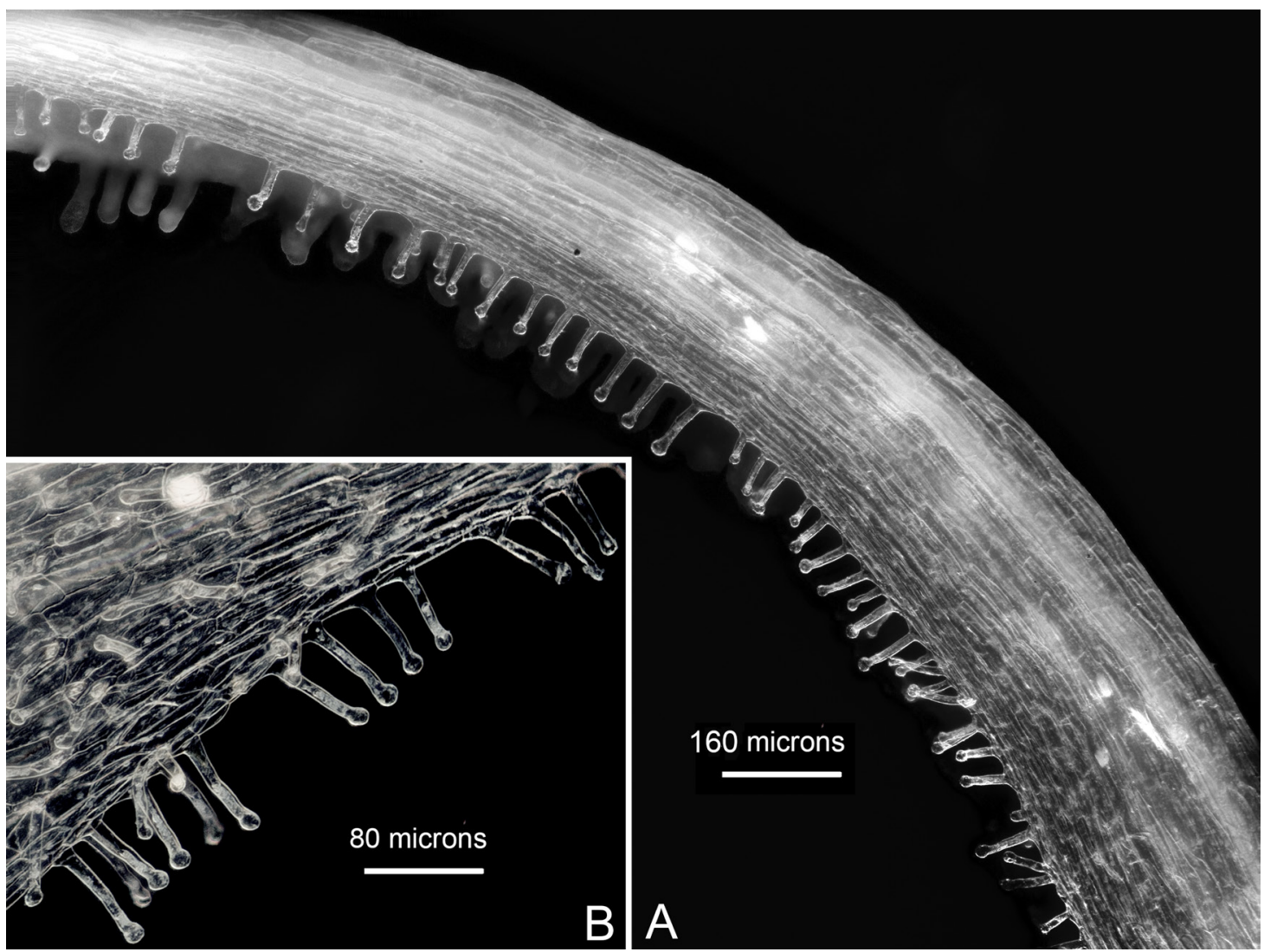

Figure 3. Platystele baqueroi. A, dorsal sepal margin. B, detail of clavate cilia. Alcohol-preserved specimen (L. Baquero 3103). Photographs by Lou Jost.

P. baqueroi and P. caudatisepala is that the former's lateral sepals are connate for $2 \mathrm{~mm}$ while the latter's sepals are free to the base. The petals of $P$. baqueroi are usually strongly reflexed, as are the outer margins of the sepals. The lip is thick in the middle, thin at the edges, and the upper (adaxial) surface is strongly convex (Fig. 4), unlike the planar lip of $P$. caudatisepala. The leaves of $P$. baqueroi are petiolate versus subpetiolate in $P$. caudatisepala.

Another similar Platystele with long sepaline tails is P. posadarum Luer \& Escobar from Colombia (Luer 1990). Platystele baqueroi differ from P. posadarum in having lateral sepals connate for $2 \mathrm{~mm}$ versus free to near the base in $P$. posadarum, smaller more narrow petals than $P$. posadarum $(4 \mathrm{~mm} \times 0.7 \mathrm{~mm}$ versus 6 $\mathrm{mm} \times 2.3 \mathrm{~mm})$, front surface of the lip featureless versus sulcate in P. posadarum, and tip of lip apiculate and deflexed versus obtuse in P. posadarum.

Platystele speckmaieri Luer \& Sijm (Luer 2010) is also superficially similar with its long-attenuate sepals. However, its sepals are free and spreading, its petals are also spreading, the lip is sulcate, contracted above the middle, narrowly obtuse at apex , and the peduncle of the inflorescence is up to $60 \mathrm{~mm}$ long versus $5 \mathrm{~mm}$ in P. baqueroi.

Conservation status: Platystele baqueroi is as yet only known from the province of Carchi, but nearby Colombia is poorly explored, and it probably occurs there as well. It should be classified as Data Deficient.

AcKNowledgemEnTs. Luis Baquero and Gabriel Iturralde thank the Ministry of the Environment for Permit 008-2016-IC-FLO-DNB/MA/MODIFICACION under which this specimen was collected. The authors thank Universidad de Las Americas, Quito, for supporting biodiversity research in Ecuador. 


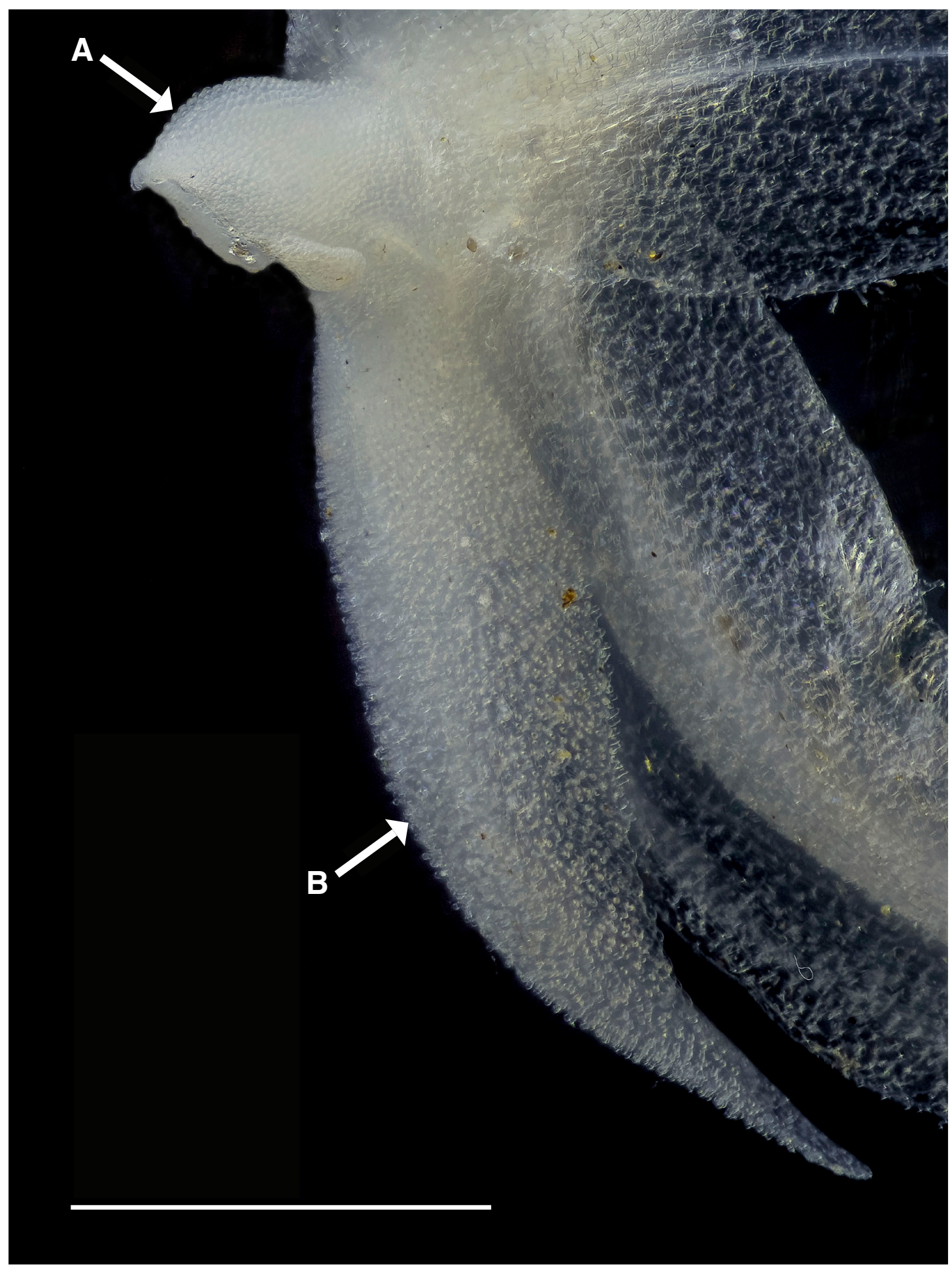

Figure 4. Platystele baqueroi. Column and lip. A, column. B, lip. Alcohol-preserved specimen (L. Baquero 3103). Scale bar $=1 \mathrm{~mm}$. Photograph by Lou Jost. 


\section{LiTERATURE CITED}

Karremans, A. P. (2016). Genera Pleurothallidinarum: An updated phylogenetic overview of Pleurothallidinae. Lankesteriana, 16 (2), 21-241.

Luer, C. A. (1990). Icones Pleurothallidinarum VII. Systematics of Platystele (Orchidaceae). Monographs in Systematic Botany from the Missouri Botanical Garden, 38, 1-184.

Luer, C. A. (1991). Icones Pleurothallidinarum VIII. Systematics of Lepanthopsis, Octomeria subgenus Pleurothallopsis, Restrepiella, Restrepiopsis, Salpistele, and Teagueia (Orchidaceae). Monographs in
Systematic Botany from the Missouri Botanical Garden, 39, 139-146.

Luer, C. A. (2010). Icones Pleurothallidinarum XXXI. Addenda: Miscellaneous new species, new name, and new combinations. Monographs in Systematic Botany from the Missouri Botanical Garden, 120, 137-154.

Pridgeon, A. M., Solano, R. \& Chase, M. W. (2001). Phylogenetic relationships in Pleurothallidinae (Orchidaceae): combined evidence from nuclear and plastid DNA sequences. American Journal of Botany, 88(12), 2286-2308. 